\title{
O IMPACTO DA CRIATIVIDADE E DO DESIGN NA COCRIAÇÃO DE EXPERIÊNCIAS TURÍSTICAS: O CASO DOS EMPREENDIMENTOS TER NA REGIÃO CENTRO DE PORTUGAL
}

THE IMPACT OF CREATIVITY AND DESIGN IN THE COCREATION OF

TOURISM EXPERIENCE: THE CASE OF RURAL ACCOMMODATION ESTABLISHMENTS IN THE CENTRAL REGION OF PORTUGAL

\section{Mafalda Marques}

Mestre em Turismo de Interior - Educação para a sustentabilidade pela

Escola Superior de Educação do Instituto Politécnico de Coimbra (Coimbra/Portugal).

E-mail: msgmarques@esec.pt.

\section{Andreia Filipa Antunes Moura}

Doutora em Turismo pela Universidade de Aveiro (Aveiro/Portugal). Professora Adjunta Convidada na Escola Superior de Educação do Instituto Politécnico de Coimbra (Coimbra/Portugal).

E-mail: andreiamoura@esec.pt. 


\section{RESUMO}

As zonas rurais de Portugal enfrentam sérios problemas de despovoamento e desertificação e os empreendimentos de Turismo em Espaço Rural (TER) parecem ser um vínculo ao positivo desenvolvimento destas zonas. O TER deverá, portanto, articular os três pilares fundamentais ao desenvolvimento sustentável: comunidade, ambiente e turista, sobre os quais devem assentar os processos criativos de cocriação de experiências turísticas que, por sua vez, poderão se beneficiar da aplicação do método de design thinking, que promove a importância do produto/serviço para atender às reais necessidades do cliente. Deste modo, o principal objetivo deste estudo é compreender a influência da criatividade e do design na cocriação de experiências turísticas. Através de um estudo qualitativo que se baseou na análise de conteúdo de 13 entrevistas semiestruturadas realizadas com proprietários de empreendimentos TER da região centro de Portugal, foi possivel apurar que, através do recurso à criatividade e ao design, é possivel obter resultados positivos ao nível da experiência oferecida ao hóspede.

Palavras-chave: TER. Experiência turística. Criatividade. Design. Cocriação.

\section{ABSTRACT}

The rural areas of Portugal are facing serious difficulties of depopulation and desertification, and the rural accommodation establishments seem to be a link to the positive development of these areas. This sort of accommodation should comprehend the three fundamental pillars to sustainable development: community, environment and tourists, on which should be based the creative processes of co-creation of tourism experiences that, in turn, may benefit from the application of the design thinking method, which promotes the importance of the product/service to meet the real needs of the client. Thus, the main objective of this study is to understand the influence of creativity and design on the cocreation of tourism experiences. Through a quality survey that was based on the content of 13 semi-structured interviews carried out with the owners of rural accommodation establishments, it was possible to verify that with the use of creativity and design, we can obtain positive results in terms of the experiences offered to the client during his stay.

Keywords: Rural Accommodation Establishments. Tourism experience. Creativity. Design. Cocreation. 


\section{INTRODUÇÃo}

Ao longo dos tempos, e com a perda de protagonismo da agricultura, o espaço rural foi sofrendo profundas alterações, tendo passado de espaço de produção a espaço de consumo. Estas alterações abriram portas à atividade do turismo nas zonas rurais, o que veio dar origem ao TR (Turismo Rural) (RIBEIRO; FREITAS; MENDES, 2001; MARTINEZ-ROGET; MOUTELA; NUÑEZ, 2015; REIS, 2012; RIBEIRO; MARQUES, 2002). Existe alguma confusão na literatura entre os conceitos de Turismo Rural (TR) e Turismo em Espaço Rural (TER). Neste trabalho optou-se por considerar TR toda a atividade turística desenvolvida em âmbito rural, e TER os empreendimentos turísticos em espaço rural cuja principal função é a de alojamento. O TR foi conquistando adeptos um pouco por todo o mundo, muito pela autenticidade da experiência que pode proporcionar, relacionando a estadia do turista com a calma da vida no campo, que contrasta com a rotina citadina a que estamos habituados nos dias de hoje.

Nesta modalidade, as comunidades locais são valorizadas, bem como os seus costumes, de forma que a experiência turística seja global e integradora. Por sua vez, a experiência turística deverá promover a competitividade de um destino, quer ao nível da qualidade dos serviços prestados, quer ao nível da criatividade aplicada nos processos, o que acaba por gerar inovação. Além disto, a experiência turística deverá ser global e memorável, integrando diversos serviços e despertando emoções e sensações ao indivíduo que a experiencia. Deste modo, colocará o turista no centro de uma rede de stakeholders, acabando por contatar diretamente com o património local, num estado de imersão. Esta proximidade leva a que a própria experiência possa ser cocriada entre turistas e comunidades locais (AGAPITO; MENDES; VALLE; ALMEIDA, 2014; BINKHORST, 2005; DALTON; LYNCH; LALLY, 2009; O0I, 2003).

A criatividade e o design, apesar de parecerem distantes do exercício do turismo, poderão ser disciplinas que the trarão bastantes benefícios. O processo de design thinking é o método criativo através do qual o design projeta um objeto, adaptando-o, por meio de testes e protótipos, o mais possível às reais necessidades do cliente, passando por um processo de exclusão de partes (CASTILLO-VERGARA; ALVAREZ-MARTIN; CABANA-VILLA, 2014; BONINI; ENDO, 2011). Caracteriza-se pela participação ativa do usuário na criação do produto final, o que nos leva a relacioná-lo com a cocriação de experiências turísticas criativas, particularmente em contexto TER.

Os objetivos deste estudo passam, essencialmente, pelacompreensão aprofundadadestas temáticas e diversas ramificações passíveis de elaborar entre elas. A principal preocupação será a compreensão da influência da criatividade e do design na experiência turística em contexto TER. Particularmente, pretende-se (i) compreender se existe procura significativa por atividades criativas em contato com a comunidade local, e quais os benefícios deste tipo de atividades; (ii) perceber se a criatividade e inovação 
são elementos presentes na gestão diária dos empreendimentos e da criação de experiências para os hóspedes; (iii) apurar a percepção da disciplina do design por parte dos proprietários, e dos benefícios que esta poderá trazer para o seu negócio.

Para a prossecução destes objetivos adoptou-se uma metodologia qualitativa, através da análise de entrevistas semiestruturadas realizadas a proprietários de empreendimentos TER situados na região centro de Portugal, formando assim uma amostra por conveniência. A recolha destes dados possibilitará a verificação de quatro hipóteses estabelecidas a partir da revisão da literatura efetuada, que respondem claramente aos quatro objetivos (principal e específicos) acima enunciados.

\section{REVISÃO TEÓRICA}

\subsection{TURISMO RURAL}

Segundo Fonseca e Ramos (2008), a atividade turística em Portugal é considerada uma mais-valia para a revitalização das economias no espaço rural. Ribeiro e Vareiro (2007) acrescentam que o Turismo Rural (TR), desde que implementado de forma sustentada, promovendo o trabalho em rede, a integração da comunidade local e o próprio património, material e imaterial, e produtos endógenos, terá tudo para resultar.

O TR surge, então, como alternativa ao turismo de massas dizendo respeito a atividades turísticas que têm lugar no espaço rural, ligadas a modos de vida tradicionais, particularmente relacionadas com a comunidade local, promovendo a sustentabilidade na exploração de recursos endógenos e proporcionando ao turista experiências genuínas (CUNHA, 2006; GIANNAKIS, 2014; UMBELINO, 1998). Trata-se, assim, de um produto turístico naturalmente de pequena escala, mas que engloba os mais diversos serviços, sejam eles de alojamento, restauração ou animação turística (LUíS, 2002), bem como recursos e atrações intrinsecamente relacionadas com o ambiente rural.

As alterações das tendências de procura, como a preferência por férias repartidas, a vontade de fuga ao ritmo frenético das cidades, o fascínio pelo rural idílico (MARTINEZ-ROGET; MOUTELA; NUÑEZ, 2015), a par com o reinventar do espaço rural que, tendo sofrido do que conhecemos por êxodo rural, passou de espaço de produção a espaço de consumo (CARVALHO, 2013), contribuíram para o positivo crescimento do TR. Contudo, de acordo com dados estatísticos do Instituto Nacional de Estatística (INE, 2015), a evolução dos empreendimentos TER tem sido mais acentuada do lado da oferta do que do lado da procura. Isto é, a estada e a taxa de ocupação médias continuam a ser um pouco menores do que o desejável, no entanto, analisando de forma geral, têm tido um crescimento gradual positivo ao longo dos anos (BARROCO; ANTUNES; AMARO, 2011; DUARTE, 2010). 
O TR adquire cada dia mais importância na promoção do espaço rural, devendo atender às questões da sustentabilidade que promovam o seu património e proporcionem ao turista uma experiência global e integradora que vá ao encontro das suas necessidades. Deste modo, parece adequado sublinhar em que consiste a experiência turística, salientando a importância da aplicação de processos criativos aquando da sua criação, para que esta, em contexto rural, possa ser, de facto, global e integradora.

\subsection{A EXPERIÊNCIA TURÍSTICA E A CRIATIVIDADE}

O espaço rural, estando repleto de elementos capazes de despertar os cinco sentidos do indivíduo, acaba por ser um espaço propício à geração de emoções, o que poderá ajudar na tarefa de criar experiências turísticas memoráveis. A experiência turística, sendo global, dita por vezes a competitividade dos destinos, mostrando a importância do trabalho em rede entre os mais diversos stakeholders para que a experiência integral seja positiva e surpreenda o visitante.

A economia de experiências, conceito explorado por Pine e Gilmore (1998), associa-se perfeitamente à atividade turística, já que o turista procura cada vez mais uma experiência global e memorável do que um destino, surge em substituição da economia de serviços e coloca o consumidor numa posição ativa e participativa da experiência.

Neste contexto, a experiência turística é multifacetada, começa logo na preparação da viagem e não termina enquanto as memórias não forem partilhadas, ou seja, prolonga-se no tempo, podendo ser influenciada por fatores externos ou internos ao turista, apresentando-se de forma diferente de indivíduo para indivíduo. Considerando os estudos de Pine e Gilmore (1998), existem quatro tipos de experiências: (1) entretenimento, (2) educacionais, (3) escapistas e (4) estéticas, sendo que estes tipos de experiência poderão ser medidos pelo nível de participação do turista e pela própria ligação que cria com a experiência.

Ora, a experiência turística, sendo influenciada por fatores externos, como o ambiente físico e o contexto social em que acontece, e fatores internos, como as necessidades e motivações do turista (KIM; FESENMAIER, 2017), acaba por ser cocriada entre turistas e comunidade local, num determinado espaço. A criatividade revela-se, deste modo, um elemento fulcral na criação de experiências turísticas, já que permitirá que esta cocriação aconteça, relacionando e valorizando recursos endógenos e criando experiências mais do que positivas, memoráveis.

Surge, assim, o turismo criativo, que traz benefícios para comunidades e empresas locais, preservando o património e contribuindo para o incremento de vendas e consequente diferenciação e atratividade do próprio destino (CARVALHO; FERREIRA; MOTA, 2016). No que diz respeito aos benefícios para a comunidade local, Richards (2012) acrescenta a sua instrução através de sinergias entre o turista 
e a população, assim como a criação de emprego e a sustentabilidade que está implícita nesta relação, levando ao desenvolvimento local. O turista está no centro da experiência e aprende, de forma lúdica, sobre aspetos práticos do local e da comunidade. A cocriação de experiências parece então garantir a aproximação dos serviços às reais necessidades do consumidor, já que é ele quem, em conjunto com a comunidade, cria a experiência. Este envolvimento promove o bom funcionamento dos destinos e a cocriação de experiências turísticas poderá, desta forma, ser considerada uma estratégia criativa para o desenvolvimento rural.

\subsection{O DESIGN E O ESPAÇO RURAL}

De acordo com Kristmann (2014), o design é uma atividade em constante mutação. Existem diversas correntes e disciplinas que lhe estão associadas, mas independentemente delas, o designer utiliza instrumentos que o auxiliam na criação de produtos ou serviços, através de processos inovadores (FORCELINI; VARNIER; FIALHO; MERINO, 2018). O design é, portanto, o ato de projetar, tendo em vista alcançar soluções inovadoras (ALMEIDA; FIALHO, 2017). Deste modo, a criatividade parece ser uma ferramenta útil, ou mesmo imprescindivel, nesta disciplina.

Por seu turno, o design thinking é um método através do qual equipas multidisciplinares procuram atender às reais necessidades dos consumidores, produzindo soluções adequadas para os mais variados problemas de diversas áreas económicas (BROWN; WYATT, 2010). Ao pressupor uma participação ativa do consumidor, promete aproximar-se das reais necessidades do público-alvo. Não poderá ser associado este processo à criação de experiências turísticas em contexto rural? Segundo Kiss (2010, citado por COSTA, MERINO, NUNES; FIALHO, 2011, p. 2), a criatividade passa pelo alargar de horizontes no campo da geração de ideias, pelo que nos parece adequado relacionar o processo de design thinking, através da busca criativa de soluções, à criação de experiências turísticas rurais que possam entrar no campo do memorável do turista que visita o destino.

Rickly e McCabe (2017) reconhecem que a essência do turismo, perante a sociedade atual, passa pela criação de experiências de viagem capazes de surpreender até os indivíduos mais exigentes. Deste modo, o setor do turismo encontra-se com um grande desafio nas mãos, que poderá eventualmente encontrar soluções através de processos típicos da área do design. Costa, Merino, Nunes e Fialho (2011) reconhecem que todo o processo de design tanto passa pela criatividade, como pelo objetivo de resolução de problemas, sendo que o design thinking envolve a relação estreita entre o pensamento abdutivo e a razão, podendo-se admitir que a margem para erro é muito reduzida, ou quase nula. E na realidade, se pensarmos no processo de design, podemos entender a criação de experiências como o problema 
que pretendemos resolver, gerando ideias inovadoras no mercado turístico atual, contribuindo para a diferenciação dos produtos ou serviços oferecidos.

\section{METODOLOGIA}

Considerando a revisão da literatura realizada, percebeu-se que o processo de criação de um produto/serviço ou, neste caso, experiência, pode beneficiar do recurso à criatividade, à inovação, ao design, e ao próprio processo de design thinking, dando origem a benefícios tanto para o empreendimento turístico que a coloca em prática, como para o turista que a experiencia. Deste modo, a questão central da presente investigação é a seguinte: "Na óptica dos operadores de TER, de que forma a criatividade e o design poderão impactar a cocriação de experiências turísticas?" Neste seguimento, e com o objetivo de dar resposta a esta questão e aos quatro objetivos específicos da investigação, acima enunciados, elaboraram-se quatro hipóteses indutivas (Tabela 1).

Tabela 1 - Hipóteses de Investigação

\begin{tabular}{l|l}
\hline No hipótese & Enunciado \\
\hline H1 & O recurso à criatividade e design resultam em impactos positivos na procura do empreendimento. \\
H2 & $\begin{array}{l}\text { O turista procura atividades criativas cocriadas com a comunidade, trazendo benefícios claros } \\
\text { para os três pilares: turista, comunidade e destino. }\end{array}$ \\
H3 & $\begin{array}{l}\text { O trabalho em rede, a par com a criatividade e inovação, permitem a criação de experiências } \\
\text { turísticas memoráveis, levando à fidelização de clientes. }\end{array}$ \\
& $\begin{array}{l}\text { O design, além de acrescentar valor estético promovendo a diferenciação do empreendimento, } \\
\text { poderá ser uma mais-valia enquanto processo que direciona a experiência às necessidades do } \\
\text { consumidor (design thinking). }\end{array}$ \\
\hline
\end{tabular}

\section{Fonte: Elaborado pelos autores}

Tendo em conta que a relação entre as disciplinas em estudo carece ainda de investigações neste sentido, e que a própria temática é relativamente subjetiva, ligada a opiniões e sensações, optou-se por realizar um estudo de índole qualitativa, que permitirá realizar uma pesquisa do tipo exploratório. Assim, criou-se um guião para realização de um inquérito por entrevista, como instrumento de recolha de dados (ver Apêndice 1). Segundo Quivy (2017), através do inquérito por entrevista, o investigador obterá informação rica e aprofundada sobre determinado tema. E, adoptou-se a análise de conteúdo 


\section{Gestãoe \\ Desenvolvimento}

como método de análise de informação, recorrendo a análises temáticas categoriais e de avaliação, bem como a análises estruturais, particularmente de ocorrências, que corroborando Quivy (2017) estudam as associações de temas nas sequências da comunicação ao longo da entrevista. Estas análises realizaramse com recurso ao software WebQDA.

Neste âmbito, optou-se por uma amostragem por conveniência não probabilística acidental, que acontece, de acordo com Coutinho (2016), quando se aproveita um grupo que está disponível no momento, por questões de praticidade. Através do Registo Nacional do Turismo (RNT), recolheram-se os nomes e contatos dos empreendimentos TER da região centro de Portugal. Foram contatados empreendimentos de Agroturismo, Casas de Campo, Turismo de Aldeia e Hotéis Rurais, num total de 100 empreendimentos. Este contato resultou em 13 entrevistas: 3 delas realizadas por email, 2 realizadas presencialmente e as restantes por telefone. As entrevistas presenciais e por telefone foram todas gravadas com autorização dos interlocutores, à exceção de um que não autorizou. Posteriormente, procedeu-se à transcrição integral das gravações das entrevistas, para inserção no programa WebQDA, com o objetivo de sistematizar a informação e poder assim ser iniciada a análise. 


\title{
4 APRESENTAÇÃO E DISCUSSÃO DE RESULTADOS
}

A amostra é composta por 13 empreendimentos das seguintes tipologias: Casas de Campo, Hotéis Rurais, Agroturismo ou outros TER. O Gráfico I permite verificar que, na sua maioria, as tipologias dizem respeito a empreendimentos de Agroturismo e Hotéis Rurais (este resultado, em particular, não corresponde ao total de 13 empreendimentos, porque alguns proprietários referiram ter mais do que uma tipologia).

\section{Gráfico I - Tipologia dos empreendimentos entrevistados}

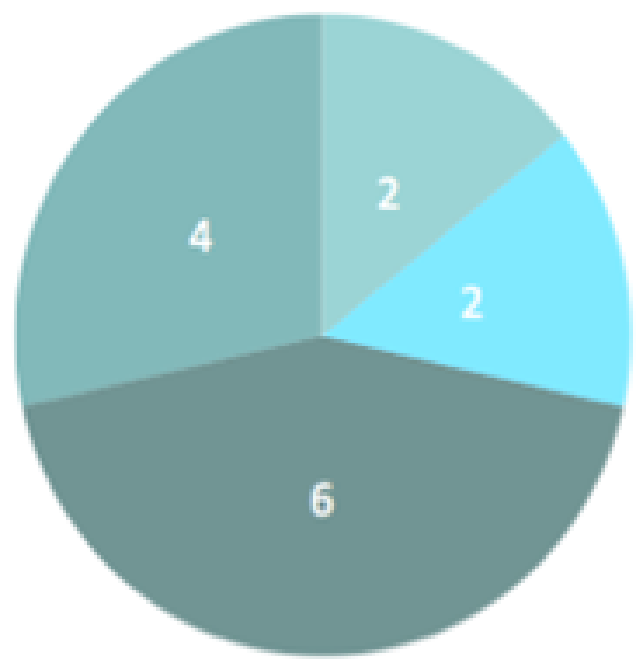

\author{
Hotel Rural \\ Agroturismo \\ Casa de Campo \\ Outros TER
}

\section{Fonte: Elaborado pelos autores}

Por sua vez, em relação ao género dos proprietários, as entrevistas revelaram alguma equidade, existindo 8 elementos do género feminino, e 7 do género masculino. No que diz respeito à idade, é possível aferir que os proprietários se encontram, maioritariamente, na faixa etária entre os 30 e os 50 anos de idade (5 elementos), sendo de referir que existe apenas uma resposta que se encaixa na faixa etária inferior a 30 anos. Relativamente à formação académica dos proprietários dos empreendimentos entrevistados, foi possivel aferir que apenas existem dois proprietários sem formação académica superior, e que a grande maioria possui o grau de licenciatura. Dos proprietários dos empreendimentos entrevistados, 7 têm formação em turismo e 8 não têm formação nesta área.

A Figura 1 representa uma nuvem de palavras mais frequentes no conteúdo das entrevistas. A palavra com mais destaque é: "pessoas", seguida das palavras "empreendimento" e "design". Algumas das 
palavras que constam na nuvem são fruto de ligações frásicas, mas conseguiram-se algumas referências que, além das já referidas, se consideram importantes, tais como: comunidade, hóspedes, experiência, turista, criatividade, procura, contato, atividades, quinta e locais. Esta nuvem de palavras acaba por introduzir os assuntos tratados na generalidade das entrevistas, que serão apresentados de seguida.

\section{Figura 1 - Nuvem de palavras mais repetidas ao longo das entrevistas}

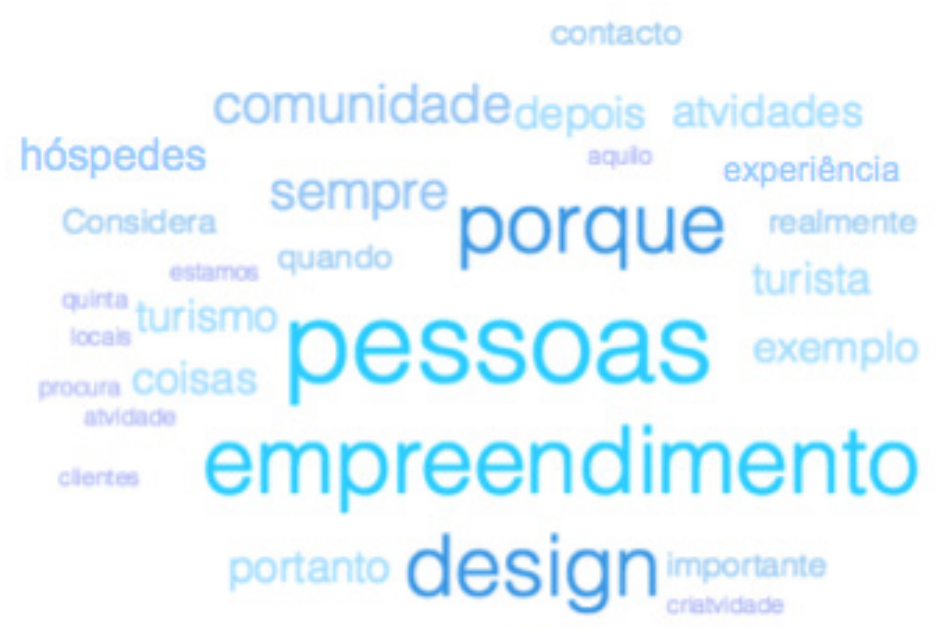

aiguma pronto

\section{Fonte: Elaborado pelos autores}

Tendo em consideração que não se pretende com esta investigação generalizar, mas sim compreender um fenómeno até aqui pouco estudado, passaremos a apresentar e discutir os resultados obtidos para cada uma das hipóteses enunciadas.

H1 - O RECURSO À CRIATIVIDADE E DESIGN RESULTAM EM IMPACTOS POSITIVOS NA PROCURA DO EMPREENDIMENTO.

Pela análise das entrevistas realizadas, parece praticamente consensual que o recurso ao design e à criatividade levam a uma maior procura dos estabelecimentos por parte dos turistas, no entanto, foi referido mais do que uma vez que "são fatores importantes, não são únicos, mas são importantes", já que 
"as pessoas cada vez mais procuram espaços únicos, que lhes transmitam uma experiência diferente do dia a dia".

a opinião de Tavares, Salvador e Moraes (2014), a inovação potencia o desenvolvimento de destinos turísticos, acabando por motivar a sua procura por parte dos turistas. Se tivermos em consideração a opinião de Richards (2012), de que a criatividade é um motor para a inovação, podemos concluir que o recurso à criatividade poderá resultar numa maior procura do empreendimento TER que a aplica.

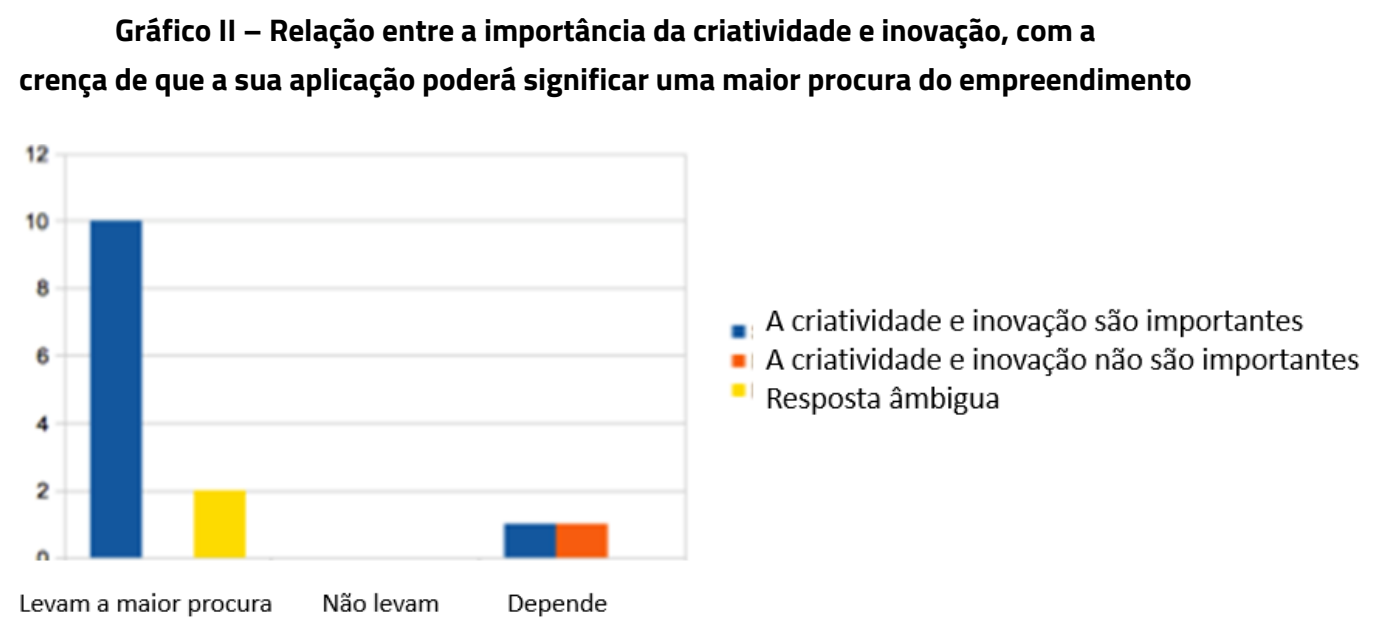

Fonte: Elaborado pelos autores

Pela leitura do Gráfico II verifica-se que quem acredita que o design e a criatividade são importantes refere maioritariamente que esses fatores resultam numa maior procura do seu empreendimento. Ainda assim, o empreendimento que considerou que não são elementos importantes revela dificuldade em concordar com o facto de eles levarem a uma maior procura do estabelecimento, tendo sido dada a resposta "depende".

Neste seguimento, a grande parte dos empreendimentos acha importante o recurso ao design, numa fase de pré-visita, muito pela imagem que transparece, nomeadamente através de plataformas como a booking ou a homeaway, que permitem ao hóspede ver fotografias do espaço, ver o logotipo e o site dos empreendimentos, levando ou não a optar por determinado empreendimento. Como referido por um dos empreendimentos, "algum arrojo na decoração, no design, no serviço" permite aferir que o design e a criatividade são elementos, embora não únicos, que permitem ao empreendimento proporcionar experiências diferenciadas dos restantes, incrementando os seus níveis de procura, já que "o design acaba 
por atrair as pessoas". Foi ainda referido por outro empreendimento que "as pessoas estão fartas dos hotéis iguais, que antes de entrar no hotel já sabem o que vão encontrar no quarto", e é através destas ferramentas que será possivel contornar esta situação. Ou seja, as pessoas são atraídas pela imagem, "a boa imagem e depois a experiência em si, mas à partida, o primeiro impacto é a imagem, e o design é muito importante nesse aspecto".

Deste modo, e apesar de ter existido uma resposta negativa à questão, a $\mathrm{H} 1$ verifica-se na maioria dos empreendimentos em estudo.

\section{H2 - O TURISTA PROCURA ATIVIDADES CRIATIVAS COCRIADAS COM A COMUNIDADE, TRAZENDO BENEFICIOS CLAROS PARA OS TRES PILARES: TURISTA, COMUNIDADE E DESTINO.}

Segundo a revisão teórica realizada evidenciou-se a ideia de que as atividades locais com turistas ou cocriadas deveriam enaltecer o potencial endógeno do próprio local (JESUS; KASTENHOLZ; FIGUEIREDO, 2008). Embora a revisão da literatura tenha revelado que a procura de atividades criativas pelos turistas era já, em meio rural, uma realidade conhecida, foram escassos os elementos obtidos nesta análise que permitissem comprová-lo. E mesmo em relação às experiências cocriadas, não foi possível obter grandes resultados que o comprovem, já que a própria relação entre o turista e a comunidade é, por vezes, um pouco mais superficial do que o imaginado. Ainda assim, percebeu-se que este envolvimento poderá trazer alguns benefícios quer para o turista, quer para a comunidade, e mesmo para o destino.

Comecemos por analisar a procura de atividades criativas e cocriadas com a comunidade por parte dos turistas que frequentam as unidades TER. Quando questionados acerca da procura de atividades criativas e/ou cocriadas com a comunidade, por parte dos turistas, foi referido que os hóspedes "não vêm cá por causa dessas atividades", sendo certo que quando chegam Ihes são apresentadas as atividades disponiveis, e depois "eles ou escolhem, ou optam por não fazer nenhuma delas". No entanto, houve 5 respostas positivas a esta procura, maioritariamente em atividades ligadas à gastronomia local e ao saber fazer popular.

Observando o Gráfico III, verificamos que na tipologia de Agroturismo existe uma maior procura por atividades criativas e em contato com a comunidade local, apesar de ser notória a maioria de respostas que afirmam não existir procura de atividades por parte dos turistas. Já a tipologia de Casas de Campo conta com menos procura de atividades, facto este que poderá ser justificado pela menor capacidade dos próprios empreendimentos, e até pela menor oferta de atividades de que dispõem. 


\section{Gráfico III - Relação entre a tipologia dos empreendimentos e a procura por atividades criativas e/ou em contato com a} comunidade local

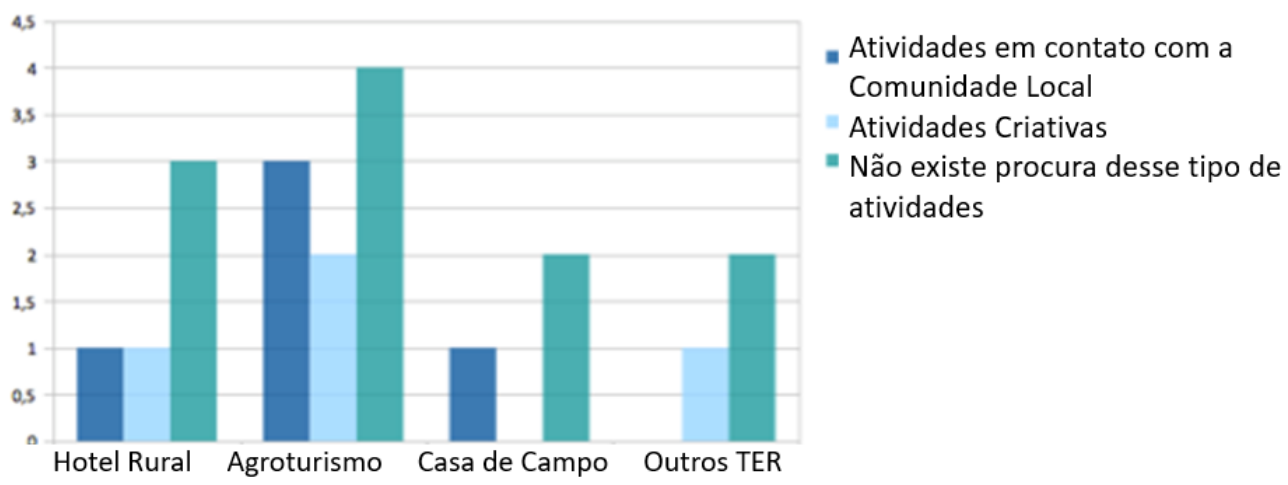

Fonte: Elaborado pelos autores

Com o objetivo de compreender se existem atividades criativas e cocriadas, pretendeu-se, então, identificar os tipos de atividades disponíveis em cada empreendimento, tanto próprias, como através de parcerias (Tabela 2). Neste contexto, verificou-se que muitos dos empreendimentos divulgam no seu estabelecimento atividades que poderão ser realizadas em parceria com outros agentes locais, ligadas ao desporto, gastronomia, visitas guiadas e até workshops, ressalvando que "o principal é a personalização de serviços. Esforçamo-nos por adequar a nossa oferta ao que cada turista pretende. Uns pretendem mais contato conosco (proprietários), outros querem andar mais por si". Neste âmbito, as atividades mais referidas são os workshops e ateliers (6 citações); as degustações e provas (5 citações) e as atividades relacionadas com a agricultura (5 citações). 
Tabela 2 - Atividades próprias disponíveis nos empreendimentos

\begin{tabular}{l|l}
\hline Experiências Turísticas & N' de citações \\
\hline Workshops e ateliers & 6 \\
Degustações e provas & 5 \\
Atividades relacionadas com a agricultura & 5 \\
Exposições e eventos culturais & 4 \\
Atividades em contato com animais & 4 \\
Atividades em contato com a comunidade local & 3 \\
Contato com a natureza & 3 \\
Venda de produtos locais & 2 \\
Atividades de Bem-estar & 2 \\
Contato com os proprietários & 2 \\
Usufruto de infraestruturas dentro do empreendimento & 2 \\
Visitas guiadas & 1 \\
\hline
\end{tabular}

Fonte: Elaborado pelos autores

Foi ainda possivel verificar que a tipologia de Agroturismo, além de possuir uma maior variedade de atividades disponíveis, possui uma maior quantidade de atividades como workshops e ateliers, atividades relacionadas com a agricultura, contato com animais e venda de produtos locais. Já na categoria de Hotéis Rurais parece haver uma preferência por exposições e eventos culturais, assim como pelas atividades de degustações e provas relacionadas com a gastronomia local. No que diz respeito às Casas de Campo, a quantidade de atividades disponíveis é um pouco mais baixa, sendo que o grupo de atividades mais referido passa pelo contato com animais.

Quanto ao envolvimento da comunidade local na atividade turística, obtiveram-se opiniões algo díspares. Em alguns casos, o contato com a comunidade é referido de forma superficial, e noutros de forma mais genuína, denotando-se uma grande preocupação com a integração da população na atividade turística. Houve apenas 3 empreendimentos que referiram a praticamente inexistência de comunidade 
que permita este contato, o que impossibilita o seu envolvimento. Mas, a maioria dos empreendimentos sublinharam a importância da comunidade, como neste caso: "Penso que eles agora já sorriem para as pessoas, já conversam também [...] por mais que eles não queiram, já fazem parte disto". Simultaneamente, em alguns casos, constatou-se a preocupação com a integração da comunidade através do fornecimento de produtos locais e da realização de atividades conjuntas.

Através da observação da Tabela 3, apura-se que grande parte dos entrevistados sublinha a autenticidade da experiência turística como o principal benefício do envolvimento da comunidade. Verificase, portanto, que o turismo acaba por beneficiar, particularmente "as unidades de restauração", já que "ao fim e ao cabo, se as pessoas se deslocarem a uma região e se tiverem uma oferta de qualidade, acabam por despender mais algum dinheiro", facto este que traz benefícios claros para o destino e comunidade. Mesmo o consumo de produtos locais dentro dos empreendimentos acaba por permitir que a população local "produza muito mais", e tenha proveito direto da atividade.

Tabela 3 - Benefícios do envolvimento da comunidade na atividade turística

\begin{tabular}{l|l}
\hline Benefícios & No $^{\mathbf{l}}$ citações \\
\hline Autenticidade da experiência apresentada ao turista & 4 \\
Movimentação de negócios locais & 4 \\
Partilha de experiências entre turistas e locais & 3 \\
Criação de emprego para a comunidade local & 3 \\
O contato com a comunidade local não existe & 3 \\
Satisfação do cliente e consequente promoção do destino & 2 \\
Melhoria de infraestruturas locais para servir o turismo & 2 \\
\hline
\end{tabular}

Fonte: Elaborado pelos autores

Neste contexto, resta compreender se o envolvimento do turista nas atividades locais poderá promover o bem-estar da região, enaltecendo o património local. Pela análise de conteúdo realizada, apercebermo-nos de que não existem grandes padrões que nos levem a crer que sim, uma vez que a maioria dos empreendimentos referem que não existe procura significativa de atividades criativas/cocriadas em contato com a comunidade, conforme referido anteriormente. No entanto, aqueles empreendimentos que 
referem a procura deste tipo de atividades, apesar de serem em menor número, acabam por dar ênfase à partilha de experiências entre a comunidade e o turista, em benefício de ambos.

As exceções que se poderão identificar passam por uma unidade que criou uma atividade intitulada de "Menu de Percursos", que consiste num menu com cinco percursos, com diferentes dificuldades descritas, que o turista poderá realizar pela região, com um gps fornecido pelo empreendimento, descobrindo assim parte da cultura regional. Podemos ainda referir um outro exemplo: ao serem realizados workshops de cozedura de pão, acaba por dar-se a conhecer, aos turistas que nele participam, os métodos adequados, regionais ou não, para a elaboração de pão.

Tomando ainda como exemplo uma atividade original promovida por um dos empreendimentos, parece adequado referir que, ao promoverem a atividade "Jantar com Locais", na qual o turista pode escolher entre seis elementos da comunidade, identificados previamente pelo hotel, cada um com um menu previamente definido, para tomar uma refeição na sua casa, acabam por promover o património gastronómico da região, além da integração da comunidade na atividade turística. Obteve-se ainda um outro exemplo, que refere uma visita organizada que dispõem a uma queijaria local, na qual o turista poderá experimentar fazer o queijo em contato com a comunidade que lá trabalha diariamente e, neste caso, observa-se também a promoção do património gastronómico da região. Neste contexto, existe ainda um empreendimento que refere a visita a feiras pagãs e medievais por parte do turista, como forma de contato direto com a comunidade, acabando por promover também o património imaterial da região onde se insere o empreendimento.

Ou seja, foi possivel identificar alguns benefícios da cocriação de experiências turísticas, quer para os turistas, quer para as comunidades locais, o que nos leva a crer que mesmo o destino turístico poderia beneficiar-se destas sinergias. No caso dos turistas, apurou-se que ganham uma maior compreensão dos modos de vida locais e tradicionais, obtendo uma experiência mais autêntica e genuína. No caso das comunidades locais, confirmou-se que para além da movimentação de negócios locais, da criação de postos de trabalho e da melhoria da qualidade de vida por criação de condições infraestruturais de que também a comunidade poderá usufruir, a partilha de experiências com diferentes culturas e o sentimento de pertença são mais-valias de referência desse envolvimento.

Segundo Cloke (2007), a experiência criativa valoriza a interação entre a população local e o turista, promovendo uma experiência global mais positiva. Na opinião de Pine e Gilmore (1998), quando surge a economia de experiências, o consumidor deixa de ser um mero espectador para criar a experiência em conjunto com os mais diversos stakeholders. Não esquecendo que uma experiência no contexto turístico será sempre cocriada (KIM; FRESENMAIER, 2017), Carvalho (2013) acrescenta que, o sucesso do TER acaba mesmo por residir na forma como são apresentadas estas atividades alternativas ao turista, 
nomeadamente através de workshops, ateliers, ou mesmo itinerários que exijam a sua participação ativa e reflitam valores locais.

Se por um lado, Jesus, Kastenholz e Figueiredo (2008) sublinham que o turista quando visita destinos de TR pretende ter contato com modos de vida local, por outro lado, Milheiro, Martins e Alves (2012) referem que o perfil de turista que procura empreendimentos TER, procura um contato com a natureza e cultura do destino que visita. No entanto, segundo a análise das respostas obtidas, não foi possível observar esta realidade, uma vez que a grande maioria dos empreendimentos refere que esta procura é apenas latente ou, quando existente, afirma-se ainda como um débil nicho de mercado.

Deste modo, e apesar de serem observáveis alguns benefícios que advêm das atividades criativas e cocriadas entre turistas e comunidade já referidos acima, considera-se que não é possível verificar a $\mathrm{H} 2$ pela escassa procura deste tipo de atividades. Contudo, nas exceções apontadas, este contato traz benefícios bastante claros.

\section{H3 - O TRABALHO EM REDE, A PAR COM A CRIATIVIDADE E INOVAÇÃO, PERMITEM A CRIAÇÃO DE EXPERIÊNCIAS TURISTICAS MEMORÁVEIS, LEVANDO À FIDELIZAÇÃO DE CLIENTES.}

Apesar de o fraco estabelecimento de parcerias entre proprietários e os diversos stakeholders do destino (MESQUITA, 2009) ter sido referido na revisão teórica como uma das ameaças ao bom funcionamento do TR, segundo os proprietários dos empreendimentos entrevistados parece que não é um hábito tão raro assim. Kastenholz et al. (2014) sublinham a importância destas sinergias, referindo que, de uma forma global, a experiência num destino acaba por ditar a sua competitividade, facto este que demonstra a necessidade de trabalho em rede de diversos agentes, com um objetivo comum: 0 incremento da qualidade da experiência holística apresentada ao turista.

Neste contexto, os empreendimentos foram questionados quanto ao seu hábito de trabalhar em rede e estabelecer parcerias com outros operadores turísticos. Conforme se verifica através do Gráfico IV e, na sua maioria, a resposta foi positiva. 


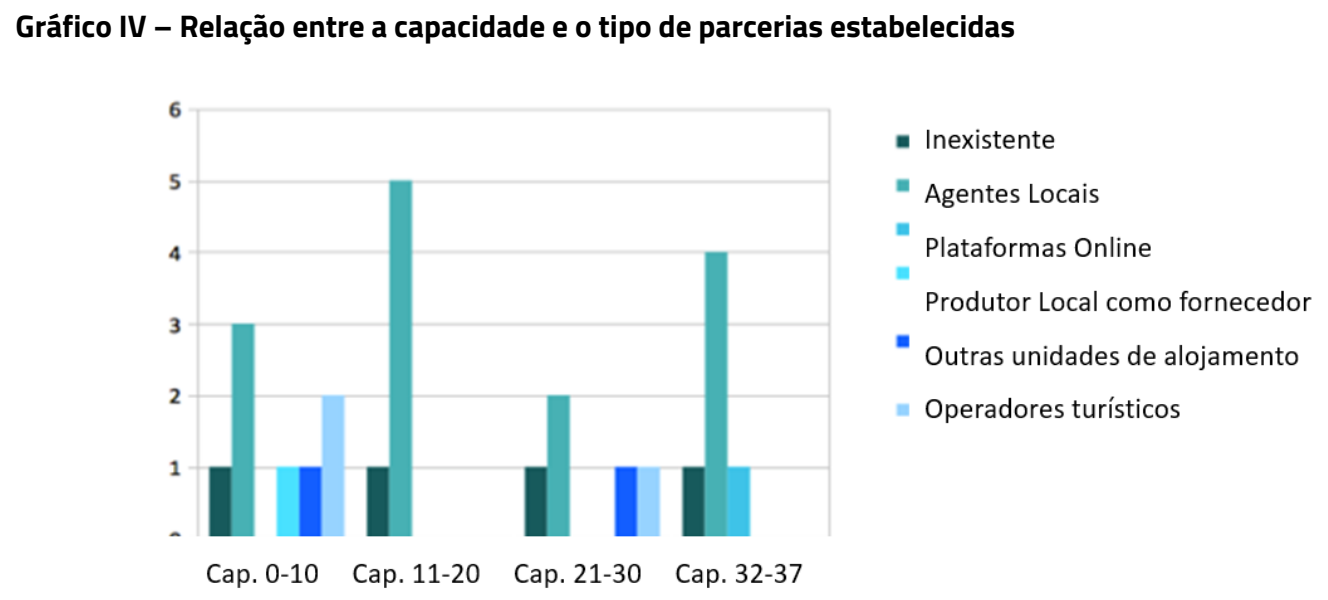

Fonte: Elaborado pelos autores

Especificamente, é observável uma ligeira diferença entre os empreendimentos de pequena dimensão, sendo que existe uma maior referência ao estabelecimento de parcerias nos dois grupos de menor dimensão, 14, do que nos dois grupos de empreendimentos de maior dimensão, 11. Relativamente aos benefícios desta colaboração, foi referido que permitia "criar ofertas complementares ao alojamento" para o turista, assim como aumentar "o volume de negócios" próprios e dos parceiros, trazendo também benefícios para a região. Ainda assim, foi referido que, "na teoria, deveriam ajudar a construir a imagem do destino e a promover-nos uns aos outros, mas na prática não resulta tão bem assim". Mais do que um empreendimento referiu, ainda que com pena, que não conseguia identificar claramente os benefícios dessas parcerias estabelecidas.

Por outro lado, a grande maioria dos proprietários TER considera a criatividade e inovação como fatores imprescindiveis no sucesso dos seus empreendimentos. Neste contexto, a Tabela 4 demonstra de que forma referem aplicá-las. 
Tabela 4 - Formas de aplicação da criatividade e inovação nos empreendimentos

\begin{tabular}{l|l}
\hline Aplicação da criatividade e inovação nos empreendimentos TER & No de citaçães \\
\hline Diferenciação de produtos e serviços & 9 \\
Atendimento personalizado & 6 \\
Arquitetura e decoração & 2 \\
Aposta na divulgação e inovação online & 2 \\
Conforto oferecido & 2 \\
Vontade de atingir diversos públicos & 1 \\
\hline
\end{tabular}

Fonte: Elaborado pelos autores

De uma forma geral, a criatividade e inovação são aplicadas mais frequentemente através da diferenciação de produtoseserviços. Nestaárea, foram-nos dados alguns exemplos deprodutos inovadores. Foi também referida a criação, "mediante a época do ano, de pacotes específicos de experiências", assim como fatores como "não ter gás, o cozinhar a lenha, o biológico", que permitem ao empreendimento em questão diferenciar-se dos restantes. Neste contexto, um outro empreendimento deu outro exemplo de inovação, nomeadamente através da criação de uma "mercearia de confiança", que apesar de ter surgido pela necessidade, revelou-se um sucesso. Segundo o proprietário do empreendimento, "não está ninguém lá. [...] Todas as casas têm um chaveirozinho, e nesse chaveiro de cada casa tem uma chave da mercearia, e as pessoas vão à mercearia sozinhas [...] as pessoas tiram o que precisam, abrem a porta, fecham, e apontam lá, e depois pagam à saída. É uma forma de inovação." O proprietário admite que não teria capacidade para colocar outra pessoa a trabalhar na mercearia, e isso acabava por representar "um problema [...], mas o problema e as dificuldades aguçam o engenho".

Quanto ao atendimento personalizado, criativo e inovador, foi referido que a forma como recebem as pessoas acaba por se refletir no seu sucesso. São referidos pequenos gestos, como a oferta de um welcome drink, conversar com o cliente, conquistar o hóspede através da "humanização do serviço", tratando cada cliente "de uma forma personalizada". No contexto da inovação ao nível da arquitetura e decoração, foi referida por um empreendimento a vontade de "inovar no espaço", sendo que a questão do aspecto exterior rústico, e o interior moderno, parece ser um contraste que "surpreende muito o hóspede". Já quanto à inovação e criatividade refletida no conforto oferecido ao hóspede, foi referido por um empreendimento que apesar de ter uma tipologia pequena, "ao mesmo tempo oferece comodidades 
de um hotel de cinco estrelas". A vontade de atingir diversos públicos acaba por ser também considerada uma forma de aplicação da inovação e criatividade, tendo sido referido por um empreendimento que vai "sempre ao encontro de um alargamento em termos do perfil do turista", já que lhes interessa captar não só "turismo sénior", mas também "casais jovens com filhos", e desta forma têm atividades que poderão captar os dois tipos de turista, por exemplo.

Comprovado que existia este trabalho em rede, e que a criatividade e inovação são fatores aplicados na gestão diária dos empreendimentos entrevistados, resta verificar se estas relações poderão originar experiências turísticas memoráveis. Os empreendimentos que possuem parcerias com agentes locais têm uma maior diversidade de oferta de atividades, e os tipos de atividades mais referidos são os workshops e ateliers, as degustações e provas, e as atividades agrícolas, experiências estas que podem refletir níveis mais elevados de criatividade do que outras apresentadas, uma vez que se podem inserir no conceito de cocriação e turismo criativo, tratando-se de experiências educacionais, pela aprendizagem de absorção ativa (PINE; GILMORE, 1998), pressupondo a integração e participação ativa do turista. Por sua vez, os empreendimentos que assumem não realizar parcerias com terceiros na sua unidade, referem em maior número de atividades como percursos pedestres e de bicicleta, e também atividades relacionadas com a agricultura, que segundo Pine e Gilmore (1998) se tratam de experiências estéticas, de imersão passiva.

Quando questionados com a hipótese de a criatividade e inovação levarem à fidelização de clientes, a maioria dos proprietários concordou com a afirmação, tendo havido apenas duas respostas negativas à questão. Richards (2012) acredita que a criatividade se trata de um estímulo à inovação e, portanto, dá origem à procura de estratégias diferenciadoras dos próprios empreendimentos. Costa, Merino, Nunes e Fialho (2011) acrescentam que a criatividade, no setor dos serviços, pretende, mais do que corresponder às necessidades do consumidor, conseguir surpreendê-lo. E qual a melhor forma de fidelizar clientes em hotelaria? Surpreendendo a cada nova visita. A maior parte dos empreendimentos acredita, geralmente, que o recurso à criatividade e inovação poderão conduzir à fidelização de clientes.

Segundo Richards (2011), a criatividade poderá trazer uma maior representatividade ao território rural, nomeadamente através da diversidade de oferta de que dispõe. Já Jager, Muller e Rootd (2013) acrescentam que a criatividade pressupõe a criação de alguma coisa inovadora. Resta saber se, aliada ao design, a criatividade será capaz de criar experiências memoráveis. Uma experiência, segundo Estaregue et al. (2017), ao despoletar sensações através dos cinco sentidos, terá mais probabilidade de alcançar o campo de memorável, porque entra nas memórias de longo prazo. Já Dalton, Lynch e Lally (2009) acrescentam que a criação de experiências memoráveis poderá representar vantagens competitivas para o destino.

Em relação às atividades disponíveis, as experiências propriamente ditas acabaram por não ser referenciadas como elementos que surpreendem o hóspede, talvez por falta de objetividade na questão 
colocada. Ainda assim, de uma leitura geral das respostas, é possivel identificar algumas situações em que acontece, por exemplo no caso do empreendimento em que é referida uma "Mercearia de Confiança", cujo proprietário acaba por referir que a sua visita e usufruto acabam por ser um momento que fica na memória do hóspede, já que é um conceito pouco comum e que leva o hóspede a vivenciar algo novo. Já outro empreendimento, por sua vez, acaba por surpreender com questões ligadas à própria produção de mirtilos do empreendimento, oferecendo aos hóspedes produtos de cultivo na quinta, despoletando sensações que darão origem a experiências, que serão com certeza recordadas. Outros elementos presentes em grande parte dos empreendimentos, que se relacionam diretamente com experiências ligadas à natureza, por exemplo, parecem ser os elementos que mais ficam na memória dos turistas. O sossego, a tranquilidade de viver no campo, o descanso. Este tipo de experiência poderá ser considerado memorável.

Com a Tabela 5 pretende-se encontrar alguns fatores surpreendentes de cada empreendimento que possam ser consideradas experiências memoráveis.

Tabela 5 - Fatores surpreendentes do empreendimento

\begin{tabular}{l|l}
\hline Fatores surpreendentes & $\mathbf{N}^{\mathbf{0}}$ de citações \\
As próprias infraestruturas & 7 \\
O atendimento & 4 \\
O conceito diferenciador & 4 \\
Surpreende por corresponder às expectativas & 2 \\
A qualidade da comida & 2 \\
A diversidade da oferta & 1
\end{tabular}

Fonte: Elaborado pelos autores

A grande maioria acredita que as próprias infraestruturas do empreendimento são o elemento que mais surpreende o hóspede (7 citações), sejam elas ao nível da arquitetura exterior ou da decoração interior.

Pela observação do Gráfico V, verifica-se que se, por um lado, o proprietário com formação em turismo considera mais surpreendente a infraestrutura do empreendimento, o proprietário sem formação em turismo, além da infraestrutura, revela a importância do próprio serviço, no que toca a distingui-lo dos restantes. 


\section{Gráfico V - Relação entre a formação em turismo e os fatores surpreendentes}

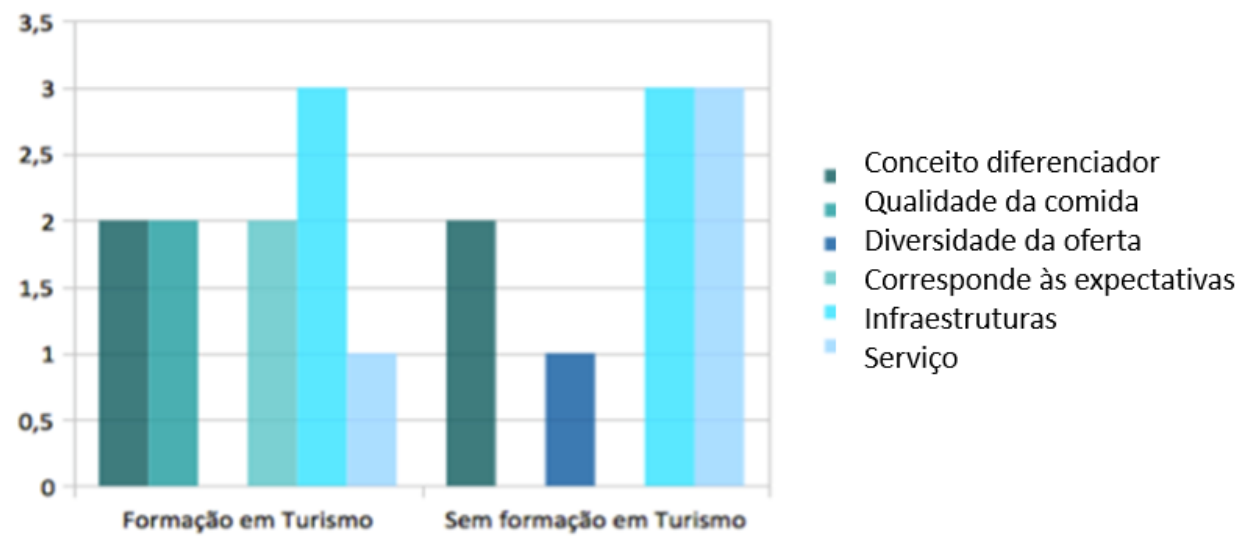

Fonte: Elaborado pelos autores

É ainda de referir que a qualidade da comida e o facto de corresponder às expectativas são fatores que surpreendem o hóspede, para o proprietário com formação em turismo, e por outro lado, para o proprietário sem formação em turismo, a diversidade da oferta é mais relevante. Quanto à tipologia, os Hotéis Rurais dão mais ênfase ao conceito diferenciador do empreendimento, os TER de Agroturismo dão mais realce às infraestruturas e ao serviço prestado. E por fim, as Casas de Campo referem em maior número as infraestruturas.

Neste contexto, e pela análise supracitada, considera-se que o trabalho em rede poderá trazer benefícios significativos à própria experiência apresentada ao turista, assim como a criatividade e inovação poderão ser elementos cruciais neste âmbito, ajudando a tornar as experiências memoráveis. Já em relação à fidelização de clientes, foi também possível apurar que poderá advir exatamente das sensações que a experiência consegue despoletar no turista, despertando a vontade de voltar e ser surpreendido novamente. Por estas razões, e apesar de não se ter obtido resultados satisfatórios aquando da pergunta direta sobre fatores que surpreendem os hóspedes, pela leitura cuidada das entrevistas percebe-se que é possível considerar que a H3 foi verificada no âmbito desta investigação. 


\section{Gestãoe \\ Desenvolvimento}

e-ISSN: 2446-6875

p-ISSN: 1807-5436

\section{H4 - O DESIGN, ALEMM DE ACRESCENTAR VALOR ESTÉTICO PROMOVENDO A DIFERENCIAÇÃO DO EMPREENDIMENTO, PODERÁ SER UMA MAIS-VALIA ENQUANTO PROCESSO QUE DIRECIONA A EXPERIÊNCIA ÀS NECESSIDADES DO CONSUMIDOR (DESIGN THINKING).}

O conceito de design é bastante abrangente e causa alguma confusão aquando da sua definição. Neste contexto, considerou-se pertinente questionar diretamente a cada um dos proprietários o que entendia por design, e perceber assim o seu entendimento. A Tabela 6 permite observar de que forma os proprietários entendem o conceito de design, para que posteriormente seja facilitada a análise ao seu recurso. Neste seguimento, o aspeto estético do design acaba por ser o elemento referido o maior número de vezes (11 citações). Por sua vez, e com sete referências, os proprietários sublinham a importância de ir ao encontro das necessidades do cliente.

\section{Tabela 6 - Conceito de design na óptica dos proprietários TER}

$\begin{array}{lr}\text { Conceito de design } & 7 \\ \text { Aspeto estético } & \\ \text { Atende às necessidades do cliente } & 5 \\ \text { Comunicação } & 3 \\ \text { Subjetivo } & 3 \\ \text { Logotipo } & 3 \\ \text { Processo criativo } & 1 \\ \text { Conceito do empreendimento } & \\ \text { Funcional } & \\ \text { Adequa-se ao espaço onde se insere } & \end{array}$

Fonte: Elaborado pelos autores

Pela análise das respostas, percebemos que a função anda por vezes de mãos dadas com o aspeto estético se, por um lado, é referido por um dos entrevistados que "um espaço com design tem de ser um espaço funcional, e tem que ser um espaço que responda àquilo que são no fundo as aspirações do próprio cliente", por outro lado, é referido que "O design é o aspeto do espaço, mas também a imagem 
do empreendimento. Além de toda a parte física e estética". No seguimento da controvérsia gerada pela primeira questão do grupo, realizaram-se algumas perguntas mais fechadas. Analisando o Gráfico VI, observa-se que é quase consensual a opinião de que o design acrescenta valor estético ao empreendimento, embora tenha existido uma resposta negativa, na categoria de Hotel Rural, e outra resposta que acredita que esse facto depende da circunstância.

\section{Gráfico VI - Relação entre a tipologia e a crença de que o design acrescenta valor estético ao empreendimento}

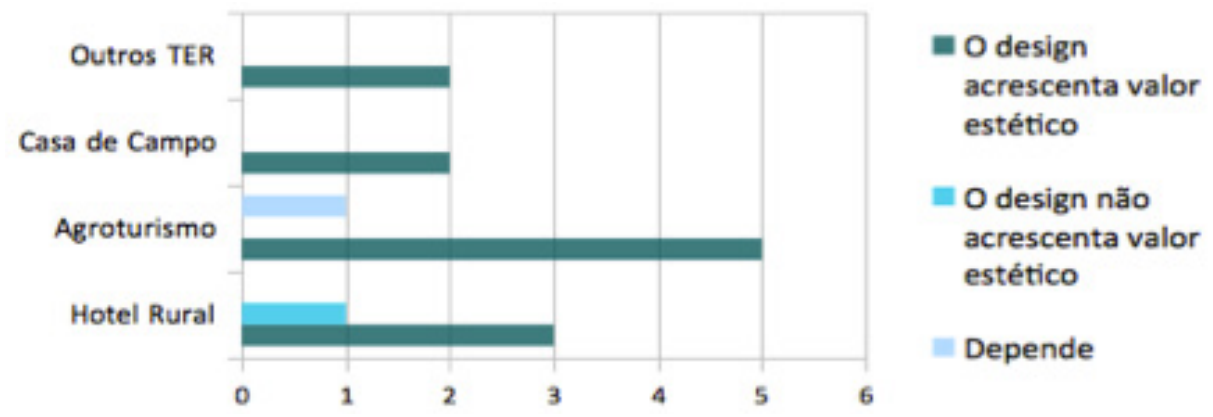

Fonte: Elaborado pelos autores

Segundo Freire (2009), a evolução do conceito de design caminhou para a criação de produtos e/ ou serviços que atendem às reais necessidades do cliente, mas, no entanto, começou por se centrar na função, e posteriormente no aspeto estético. Assim sendo, não parece descabido que os empreendimentos reconheçam o seu valor estético, no que toca à diferenciação do empreendimento.

Por sua vez, em relação ao facto de o design promover a diferenciação de um empreendimento, mais uma vez, as respostas foram quase todas positivas. No entanto, foi referido que "não é o primeiro critério" para a escolha do empreendimento, uma vez que "se a pessoa tiver restrições financeiras, acho que não". Procurou-se ainda compreender se a tipologia do empreendimento poderá ter influência nos elementos que consideram diferenciadores entre empreendimentos.

É então possível concluir que a grande maioria dos empreendimentos acredita que o design, além de acrescentar valor estético ao empreendimento, promove a sua diferenciação. A única resposta que se revelou reticente em concordar com uma das afirmações acabou por demonstrar também alguma relutância em concordar com a outra. E uma das que não concorda que o design promove a diferenciação, acredita que, ainda assim, o design acrescenta valor estético ao empreendimento.

Neste sentido, considerou-se pertinente analisar, também por tipologia, quais os fatores considerados diferenciadores de cada um dos empreendimentos. 


\section{Gráfico VII - Relação entre a tipologia e os fatores diferenciadores dos empreendimentos}

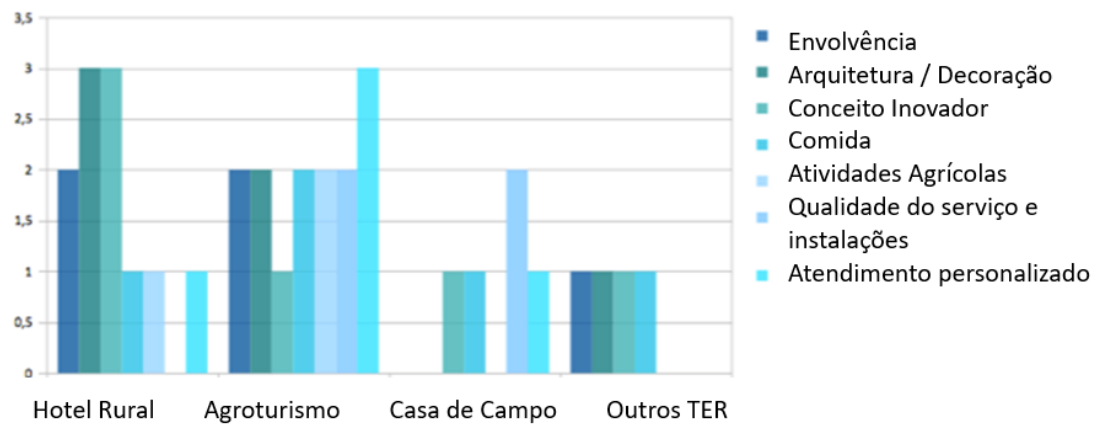

Fonte: Elaborado pelos autores

Neste contexto, e pelo Gráfico VII, pode compreender-se que os Hotéis Rurais dão mais ênfase à arquitetura e decoração, assim como ao próprio conceito do empreendimento. Por sua vez, nos empreendimentos de Agroturismo, o atendimento personalizado tem um maior peso neste âmbito. Por fim, a tipologia de Casas de Campo revela que a qualidade do serviço e das próprias instalações é o que distingue o seu empreendimento.

Segundo Brown e Wyatt (2010), o processo de design thinking, atividade anteriormente apenas ligada à profissão do designer, poderá ser aplicado a outras áreas de negócio. Trata-se de um processo que busca várias soluções para determinado problema, seja ele um produto ou serviç̧o, chegando a conclusões através da observação das reais necessidades do consumidor, através de protótipos e testes, sendo que este processo será sempre alicerçado nos valores da criatividade. Já Binkhorst (2005) acrescenta que o consumidor dos dias de hoje é mais atento e informado, optando por obter maior controle sobre as experiências que vivencia, o que leva a crer que a necessidade de diálogo entre a entidade que cria a experiência e o consumidor adquire cada vez mais importância. Através da observação atenta das necessidades, o produto final será sempre mais bem-sucedido.

Neste âmbito, e com o objetivo de compreender se existia uma procura, por parte dos proprietários, em ouvir sugestões e críticas tendo em vista direcionar os serviços e a própria infraestrutura para as necessidades do cliente, apresenta-se o Gráfico VIII. 
Gráfico VIII - Relação entre a tipologia e a reação à crítica

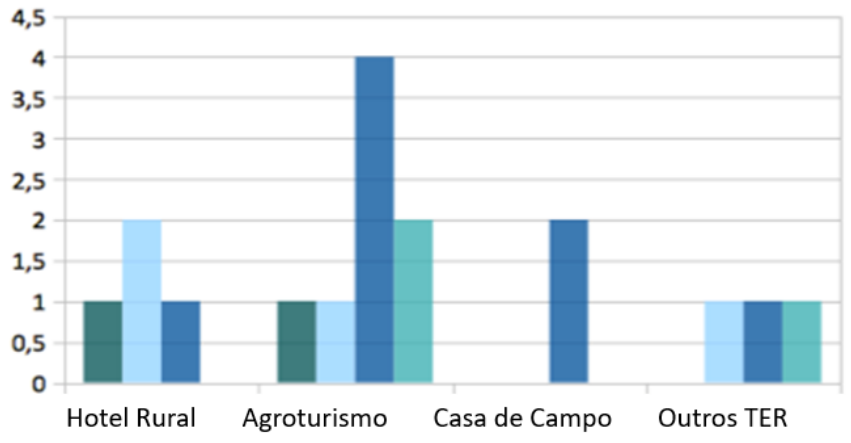

= As críticas não resultam em melhoramentos

El Depende da circunstância

- As críticas resultam em melhoramentos

não têm críticas

\section{Fonte: Elaborado pelos autores}

Se por um lado, nos Hotéis Rurais referem, em maioria, que esses melhoramentos dependerão sempre das circunstâncias, por outro lado, nos empreendimentos de Agroturismo e Casas de Campo parece mais consensual a resposta afirmativa. No entanto, apenas nas Casas de Campo esta resposta é consensual. Nos Hotéis Rurais e nos empreendimentos de Agroturismo registou-se uma resposta negativa à afirmação.

Pela análise das respostas obtidas, foi possível verificar que existe, por parte dos empreendimentos, e salvo raras exceções, interesse em ir ao encontro das necessidades dos clientes, quer no serviço, quer nas experiências, quer nas próprias infraestruturas do empreendimento. Esta preocupação é evidenciada por um dos empreendimentos quando refere que "mesmo durante a estadia do hóspede, nós preocupamo-nos em saber qual é a opinião dele. (...) nós revemo-nos muito na opinião do cliente, e logicamente que a registramos, e temos em conta, portanto não somos indiferentes, mas nós somos os primeiros a procurá-los".

Visto que é consensual que o design acrescenta valor estético e promove a diferenciação dos empreendimentos, resta analisar a sua relação com o processo de design thinking. Se pensarmos que o processo de design thinking passa essencialmente pela criação do produto final a par e passo entre 0 produtor e o consumidor, através de testes que permitem aprimorar o produto final, e tendo em conta que o turismo, e mesmo os empreendimentos TER, estão em constante mutação, tomando em atenção as críticas para corresponder às necessidades dos consumidores, parece verificável que será possível adaptar este processo à criação de experiências turísticas, e que de certa forma seja já posto em prática, ainda que inconscientemente. Como tal, considera-se a $\mathrm{H} 4$ verificada. 


\section{CONSIDERAÇÕES FINAIS}

Através da análise e discussão de resultados, foi possivel responder ao principal objetivo proposto para o desenvolvimento do presente estudo, permitindo a melhor compreensão da influência da criatividade e do design na cocriação de experiências turísticas em contexto TER, verificando-se três das quatro hipóteses previamente colocadas: (i) 0 recurso à criatividade e design resultam em impactos positivos na procura do empreendimento $(\mathrm{H} 1)$; (ii) $\mathrm{O}$ trabalho em rede, a par com a criatividade e inovação, permitem a criação de experiências turísticas memoráveis, levando à fidelização de clientes (H3); (iii) 0 design, além de acrescentar valor estético promovendo a diferenciação do empreendimento, poderá ser uma mais-valia enquanto processo que direciona a experiência às necessidades do consumidor $(\mathrm{H} 4)$;

Em termos de implicações teóricas, o presente estudo poderá então ser considerado um importante contributo para estabelecer uma interligação coerente entre áreas de conhecimento, à partida distantes, mas afinal com bastantes pontos de ligação possivel: a criatividade, o design e o turismo. Neste sentido, sublinha-se que o design, enquanto disciplina, poderá trazer contributos significativos, quer ao próprio empreendimento turístico, quer através do seguimento do processo de design thinking, à criação de experiências turísticas rurais, integradoras e memoráveis. Ou seja, também no que diz respeito a implicações práticas, esta investigação poderá ajudar empreendimentos TER a compreender a importância destas disciplinas, transpondo-as para a sua própria estratégia empresarial.

Quanto aos objetivos específicos, compreendeu-se que (1) a procura por atividades criativas em contacto com a comunidade local é ainda um pouco escassa. De todo o modo, caso aconteça, a maioria dos empreendimentos reconhece que poderia trazer benefícios tanto para a comunidade, como para o turista, e implicitamente para o destino, tais como: troca de experiências entre diferentes culturas, sentimento de pertença na comunidade e aumento da produção local, assim como a criação de infraestruturas para servir o turismo das quais o destino acaba por usufruir; (2) a criatividade e inovação são elementos presentes na gestão diária dos empreendimentos, ganhando cada vez mais destaque no exercício do turismo, acabando mesmo por conduzir à fidelização de clientes. Já no campo da criação de experiências para os hóspedes, a criatividade e inovação revelam-se importantes e potenciais motores de criação, no entanto, são ainda pouco aplicados pela maioria dos empreendimentos TER entrevistados, pelo menos de forma consciente; (3) a disciplina do design é compreendida pelos proprietários de formas bastante diferentes, ainda assim, quase todos reconhecem a importância de lhe recorrer nos mais diversos campos, seja para incrementar o valor estético do empreendimento, para aliar a forma à função, ou mesmo para corresponder às necessidades do cliente, o que nos leva a crer que o processo de design thinking poderá 
ser um bom contributo para a criação de experiências turísticas em contexto rural, conduzindo o produto final para as reais necessidades do consumidor.

Ainda assim, considera-se pertinente referir que os resultados poderiam ter sido mais reveladores caso a amostra tivesse sido mais significativa. Num futuro projeto de investigação, e para que os resultados possam ter uma maior representatividade, seria adequado aplicar o estudo a uma amostra maior, a nivel nacional, ou até internacional, permitindo assim análises mais aprofundadas, generalizadas, e consequentemente uma compreensão mais alargada da aplicação da criatividade e design à cocriação de experiências turísticas. Esta análise mais abrangente permitia estabelecer padrões de resposta, ou até mesmo comparação entre implicações, dando origem a resultados ainda mais satisfatórios.

Em suma, a presente investigação constata a importância da aplicação de processos criativos na cocriação de experiências turísticas por parte de empreendimentos TER na região centro de Portugal, quer através da inovação em produtos, serviços e/ou atividades oferecidas, quer no próprio aspeto estético do empreendimento, firmando relevantes linhas orientadoras para o desenvolvimento de investigações transversais e longitudinais para o futuro.

\section{REFERÊNCIAS}

AGAPITO, D.; MENDES, J.; VALLE, P. ; ALMEIDA, H. Um contributo do marketing sensorial para o marketing da experiência turística rural. Pasos - Revista de Turismo y Patrimonio Cultural, Islas Canárias, v. 12, n³, p. 611-621, mai. 2012.

ALMEIDA, F.; FIALHO, F. Conceito em construção: considerações sobre a definição de Design Gráfico ao longo dos anos. Projética, Londrina, v. 8, n², p. 83-95, jul. 2017.

BARROCO, C.; ANTUNES, J.; AMARO, S. Turismo em espaço rural: tendências e oportunidades. In: Actas Gestão de Bens Comuns e desenvolvimento regional sustentável Bragança-Zamora, 17. o CONGRESSO DA APDR, 5. o Congresso de Gestão e Conservação da Natureza Congresso Internacional da APDR/ AECR, Bragança-Zamora, 2011, p. 666-683.

BINKHORST, E. The Co-creation tourism experience. Sitges: Whitepaper Co-Creations, 2005.

BONINI, L. A.; ENDO, G. D. B. Design thinking: uma nova abordagem para inovação. Biblioteca Terra Fórum Consultores, 2011. Disponivel em: <file://C:/Users/HP/Downloads/Design\%20Thinking\%20Uma\%20 Nova\%20Abordagem\%20d a\%20lnovacao.pdf>. Acesso em: mar. 2018. 
BROWN, T.; WYATT, J. Design Thinking for Social Innovation. Stanford Social Innovation Review, p. 3035, jul. 2010.

CARVALHO, R.; FERREIRA, A. M.; MOTA FIGUEIRA, L. Cultural and Creative tourism in Portugal. PASOS, revista de turismo y patrimonio cultural, Islas Canárias, v. 14, n5, p. 1075-1082, out. 2016.

CARVALHO, M. S. Cultura e turismo criativo na experiência integral do turismo rural. 2013. Dissertação (Mestrado em "Gestão e Planeamento em Turismo") - Universidade de Aveiro, Aveiro, Portugal, 2013.

CASTILLO-VERGARA, M.; ALVAREZ-MARIN, A.; CABANA-VILLA, R. Design Thinking: como guiar a estudiantes, emprendedores y empresarios en su aplicación. Red de Revistas Científicas de América Latina, La Habana, v. 35, n³, p. 301-311, dec. 2014.

CLOKE, P. Creativity and tourism in rural environments. Tourism, creativity and development, Londres, v. 23, n²4, p. 37-47, jan. 2007.

COSTA, A.; MERINO, G.; NUNES, J.; FIALHO, F. O pensamento criativo e o design. Con- vergências: Revista de Investigação e Ensino das Artes, Castelo Branco, v. 4, n8, p. 1-11, 2011.

CUNHA, L. Economia e política do turismo. Lisboa: Edições Verbo, 2006.

DALTON, R; LYNCH, P. ; LALLY, A. M. Towards an understanding of experience concept development in tourism service design. Helsinki, Finland: EuroCITRIE, p. 22-24, out. 2009.

DUARTE, P. Evolution of rural tourism in Portugal: a 25 years analysis. E-Review of Tourism Research (eRTR), Beira Interior, v.8, n³, p. 41-56, jun. 2010.

ESTAREGUE, D.; MERINO, G. S. A. D.; MERINO, E. A. D.; GONÇALVES, M. M. Design experiencial no turismo: uma revisão integrativa sobre o tema. Revista Iberoamericana de Turismo - RITUR, Penedo, Alagoas, v. 7, n¹, p. 85-100, jan./abr. 2017.

FONSECA, F.; RAMOS, R. Dinâmicas do turismo em espaço rural em regiões de baixa densidade: 0 exemplo de Almeida. Coimbra: Communication VII Colóquio Ibérico de Estudos Rurais, 2008.

FORCELINI, F.; VARNIER, T.; FIALHO, F.A.P. ; MERINO, E.A.D. As técnicas de criatividade no processo de design. Temática, v. 1, nº1, p. 31-46, jan. 2018.

FREIRE, K. Reflexões sobre o conceito de design de experiências. Strategic Design Journal, v. 2, nº , p. 37-44, jan./jun. 2009. 
GIANNAKIS, E. The role of rural tourism on the development of rural areas: The case of Cyprus. Romanian Journal of Regional Science, Roménia, v.8, n¹, p. 38-53, jun. 2014.

INE-Portugal, Estatísticas do Turismo 2015. Lisboa: Instituto Nacional de Estatística, IP, 2015.

JAGER, C.; MULLER, A.; ROODT, G. Developing creative and inovative thinking and problem-solving skills in a financial services organisation. SA Journal of Human Resource Management, v. 11, $n^{\circ} 1$, p. 1-10, mai. 2013.

JESUS, L.; KASTENHOLZ, E.; FIGUEIREDO, E. A oferta do turismo no espaço rural: o caso da região dão-lafões. Coimbra: VII CIER - Cultura, Inovaç̧ão e Território, 2008.

KASTENHOLZ, E.; EUSÉBIO, C.; SOUSA, A.J.; CARVALHO, M.; LIMA, J.; CARNEIRO, M. J.; FIGUEIREDO, E.; PATO, L.; BREDA, Z.; CUNHA, C.; MARQUES. C.; LOUREIRO, S.; MOTA, A.C.; LAVRADOR SILVA, A; PEREIRO, X.; CAPELA, C. Desafios para a cocriação de experiências turísticas rurais sustentáveis. In: KASTENHOLZ, E.; EUSÉBIO, C.; FIGUEIREDO, E.; CARNEIRO, M. J.; LIMA, J.(COORDS.) Reinventar o Turismo Rural em Portugal - Cocriação de experiências turísticas sustentáveis, Aveiro: UA Editora, 2014. p. 125-142.

KIM J.; FESENMAIER D.R. Tourism Experience and Tourism Design. In: FESENMAIER D., XIANG Z. (EDS) Design Science in Tourism. Tourism on the Verge, Springer International Publishing Switzerland: Cham, 2017.

KRISTMANN, V.B. Interdisciplinaridade: questões quanto à pesquisa e à inovação em design. Estudos em Design, Rio de Janeiro, v. 22, n³, p. 81-99, 2014.

LUIS, E. Turismo no espaço rural em Portugal. GeolNova, v. 5, p. 139-152, 2002.

MARTÍNEZ-ROGET, F.; MOUTELA, J. A. T.; NÚÑEZ, J. C. E. Chaves do êxito do Turismo em Espaço Rural (TER): evidências a partir da lealdade turística na Rede das Aldeias do Xisto. Revista Portuguesa de Estudos Regionais, Angra do Heroísmo, v. 40, p. 65-81, 2015.

MESQUITA, A. M. V. Sistemas de distribuição no turismo em espaço rural TER a região de Trás-os-Montes. Dissertação (Mestrado em "Gestão e Desenvolvimento em Turismo") - Universidade de Aveiro, Aveiro, Portugal, 2009.

MILHEIRO, E.; MARTINS, A.; ALVES, J. E. 0 rural como espaço de empreendedorismo em turismo. Portalegre: O Futuro do Mundo Rural em Questão: Atas do I Congresso de Estudos Rurais do Norte Alentejano, 2014.

OOI, C. S. (2003). Crafting Tourism Experiences: Managing the Attention Product. Stavanger: Paper presented at the 12th Nordic Symposium on Tourism and Hospitality Research, 2-5 october 2003. 
PINE, B. J.; GILMORE, J. H. Welcome to the experience economy. Harvard business review, v. 76, n4, p. 97-105, jul./ago. 1998.

QUIVY, R. Manual de Investigação em Ciências sociais. Lisboa: Gradiva, 2008.

REIS, P. Desenvolvimento local: o binómio turismo/áreas rurais nas estratégias de desenvolvimento local. Exedra: Revista Científica, Portalegre, v. 6, p. 155-172, 2012.

RICHARDS, G. Creativity and tourism: The state of the art. Annals of tourism research, The Netherlands, v. 38, n०4, p. 1225-1253, jul. 2011.

RICHARDS, G. Tourism, Creativity and Creative Industries. Breda: Creativity and Creative Industries in Challenging Times, NHTV, nov. 2012.

RIBEIRO, M.; MARQUES, C. Rural tourism and the development of less favored areas: between rhetoric and practice. International journal of tourism research, Faro, v. 4, n³, p. 211-220, mar. 2002.

RIBEIRO, J. C.; FREITAS, M. M. D.; MENDES, R. B. 0 turismo no espaço rural: uma digressão pelo tema a pretexto da situação e evolução do fenómeno em Portugal. Minho: Working paper series, Nucleo de Investigação em Políticas Económicas, Universidade do Minho, jan. 2001.

RIBEIRO, J. C.; VAREIRO, L. C. Turismo e desenvolvimento regional: $\mathbf{0}$ espaço rural como destino turístico. Arcos de Valdevez: Atas do 1o Congresso Internacional Casa Nobre: um património para o futuro, p. 470-486, nov. 2007.

RICKLY, J. M.; MCCABE, S. Authenticity for Tourism Design and Experience. In: FESENMAIER, D., \& XIANG, $Z$. (eds) Design Science in Tourism . Tourism on the Verge Springer, Springer International Publishing Switzerland: Cham, 2017.

TAVARES, J. M.; SALVADOR, R.; MORAES, G. V. Modelo de geração de inovações em um ambiente de recursos escassos (MGIARE): uma aplicação ao turismo. Revista de Administração e Inovação, v. 11, n4, p. 110-134, 2014.

UMBELINO, J. Turismo em espaço rural: da utopia à realidade. In: PINTASSILGO, J., TEIXEIRA, M. (ED.), Turismo Horizontes Alternativos, p. 175-188. Lisboa: Edições Colibri. 1998 


\section{APÊNDICE 1 - GUIÃO DE ENTREVISTA}

\section{IDENTIFICAÇÃO DO EMPREENDIMENTO E PROPRIETÁRIO}

\begin{tabular}{|c|c|c|}
\hline \multirow{4}{*}{ Identificação do Empreendimento } & Nome & \\
\hline & $\begin{array}{l}\text { Tipologia (Casa de Campo, Agro-turismo, Hotel } \\
\text { Rural...) }\end{array}$ & \\
\hline & Capacidade ( $n^{\circ}$ camas) & \\
\hline & Concelho & \\
\hline \multirow{5}{*}{ Identificação do Proprietário } & Sexo & \\
\hline & Idade & \\
\hline & Habilitações Literárias & \\
\hline & Possui formação na área do Turismo? & $\begin{array}{l}\mathrm{SIM}_{---} \mathrm{NÃO}_{---} \\
\text {Qual? }-----------------\end{array}$ \\
\hline & Possui outra atividade profissional? & $\begin{array}{l}\mathrm{SIM}_{---} \mathrm{NAOO}_{---} \\
\text {Qual? }-----------------\end{array}$ \\
\hline
\end{tabular}

\section{TURISMO EM ESPAÇO RURAL}

2.1. Quais são para si os recursos mais relevantes da região onde se insere o seu empreendimento?

2.1.1. Pensa que essas são as razões pelas quais o turista escolhe o empreendimento para pernoitar? Por que razão?

2.2. Habitualmente, costuma estabelecer parcerias com outros operadores turísticos da região? Se sim, quais são para si os benefícios dessa colaboração?

2.3. Na sua opinião, qual o papel da comunidade local na atividade turística?

2.3.1. De 0 a 5, qual o nível de envolvimento do turista com a comunidade local?

2.3.2. Poderá exemplificar de que forma o turista estabelece esse contacto?

2.3.3. Quais as mais-valias para a comunidade local/destino turístico com o envolvimento dos turistas em atividades locais? 


\section{A EXPERIÊNCIA TURÍSTICA}

3.1. De que tipo de experiências turísticas poderá o hóspede usufruir ao recorrer aos seus serviços?

3.1.1. Existe algum tipo de programa pré-definido de atividades de animação e entretenimento relacionadas com o património e tradições locais?

3.2. O turista que vos visita, costuma procurar atividades criativas em contacto com a comunidade local? Quais?

3.3. Considera a criatividade e inovação fatores importantes na sua área de negócio?

3.3.1. Se sim, de que forma os aplica?

3.4. Pensa que a criatividade e inovação têm contribuído para a fidelização de clientes?

3.4.1. De que forma?

3.5. Quais as estratégias utilizadas para desenvolver o seu empreendimento?

3.6. Em que é que o seu empreendimento se distingue dos restantes da mesma zona geográfica?

\section{O DESIGN NO EMPREENDIMENTO}

4.1. O que entende por design?

4.2. Considera o design importante para o sucesso de um empreendimento TER? Em que aspetos?

4.2.1. Considera que o design acrescenta valor estético ao empreendimento?

4.3. Considera que o recurso ao design e criatividade resultam numa maior procura do seu estabelecimento? Porquê?

4.4. Acha que o design pode ajudar na diferenciação de um empreendimento? De que forma?

4.5. Neste contexto, qual ou quais os momentos em que sentiu que o seu empreendimento, pelas suas características, realmente conseguiu surpreender os seus hóspedes?

4.6. As críticas e sugestões dos hóspedes (no que toca ao design do empreendimento) costumam resultar em melhoramentos do espaço? Se sim, exemplifique. Se não, por que razão? 